\title{
FAKTOR-FAKTOR YANG MEMPENGARUHI KUALITAS LAYANAN WEBSITE BANK SYARIAH TERHADAP PEROLEHAN INFORMASI NASABAH (STUDI BNI SYARIAH KOTA BOGOR)
}

\section{FACTORS THAT INFLUENCE THE QUALITY OF SHARIA BANK WEBSITE SERVICES TOWARDS CUSTOMER INFORMATION (BNI STUDY OF SHARIA BOGOR CITY)}

\author{
Nurma Yunita1a \\ 1aProgram Studi Perbankan Syariah Fakultas Ekonomi Islam Universitas Djuanda, Jl. Tol Ciawi No. 1, \\ Kotak Pos 35 Bogor 16720, email: Yunitanurma303@gmail.com
}

\begin{abstract}
This study aims to determine the most dominant factors affecting the quality of BNI syariah website services to obtain customer information in Bogor. The research method uses a questionnaire technique derived from 100 respondents of BNI Syariah customers in Bogor city. The results of this study indicate that navigation systems are accessibility, content, relevant, trust is the most dominant factor or the main factor to determine the quality of the services of the BNI Syariah website on obtaining customer information. Whereas website design factors up to date information transaction security, ease of communication are the supporting factors for the quality of BNI Syariah website services for customer information acquistion
\end{abstract}

Keyword: Islamic bank, quality, service, website, information

\begin{abstract}
ABSTRAK
Penelitian ini bertujuan untuk mengetahui faktor-faktor yang paling dominan mempengaruhi kualitas layanan website BNI Syariah terhadap perolehan informasi nasabah di Kota Bogor. Metode penelitian menggunakan pendekatan kuantitatif dengan teknik analisis faktor. Teknik pengumpulan data menggunakan teknik kuesioner yang berasal dari 100 responden nasabah BNI syariah yang berada di Kota Bogor. Hasil penelitian ini menunjukan bahwa sistem navigasi, aksesibilitas, konten, relevan, kepercayaan merupakan faktor yang paling dominan atau faktor utama untuk mengetahui kualitas layanan website BNI Syariah terhadap perolehan informasi nasabah. Sedangkan faktor desain website, informasi terkini, keamanan bertransaksi, kemudahan berkomunikasi merupakan faktor pendukung untuk kualitas layanan website BNI Syariah terhadap perolehan informasi nasabah.
\end{abstract}

Kata Kunci: bank syariah, kualitass, layanan, website, informasi

Nurma Yunita. 2020. Faktor-Faktor Yang Mempengaruhi Kualitas Layanan Website Bank Syariah terhadap Perolehan Informasi Nasabah (Studi BNI Syariah Kota Bogor). Jurnal Nisbah 6 (1): 30-41. 


\section{PENDAHULUAN}

Kemajuan teknologi telah merubah perilaku konsumen kearah modernisasi yang menuntut konsumen bergerak sigap dalam mengikuti cepatnya perkembangan teknologi. Sudah sebagian besar masyarakat melibatkan teknologi informasi dalam kesehariannya, khususnya internet dan website (Hanifa, 2017:1). Teknologi telah mengubah dunia bisnis menjadi lebih cepat dan efisien. Bahkan saat ini, hampir semua sektor membutuhkan peranan dari teknologi tersebut, maka dapat mmpermudah jalannya pekerjaan sehingga diangap sangat penting bagi sebagian besar masyarakat (Sihotang, 2010:25).

Kebutuhan teknologi ini juga menyentuh sektor perbankan yang memunculkan layanan dengan basis teknologi informasi. Pelayanan ini dimaksudkan agar nasabah lebih mudah dalam melakukan setiap transaksinya tanpa harus datang ke bank dan berhadapan langsung dengan teller (Bank Indonesia). Teknologi internet mampu memberikan layanan yang terbaik kepada nasabah karena adanya kecepatan, kemudahan, fleksibilitas kenyamanan dan tersedia layanan $7 \times 24$ jam. Demikian beberapa perbankan menganggap transformasi digital sebagai hal baru berbisnis karena potensinya untuk menghemat biaya dan mengolah pola pikir sesuai perilaku dan kebutuhan masyarakat (Bimo, 2018:15). Salah satu teknologi internet yang digunakan adalah layanan multimedia atau lebih dikenal dengan website yang merupakan layanan terpenting dari internet (Utama, 2011:359).

Website saat ini menjadi keharusan bagi perbankan yang ingin merangkul nasabahnya website mampu menyediakan informasi dalam bentuk teks, gambar, suara, dan gambar bergerak akan tetapi umumnya web seperti ini masih bersifat statis dan tidak dapat mengolah data (Utama, 2011:360).
Website perbankan akan memberikan informasi bagi nasabahnya dengan tujuan untuk memberikan kemudahan dalam melakukan transaksi perbankan kepada setiap nasabahnya. Teknologi informasi website ini harus dapat meningkatakan kualitas pengambilan keputusan bagi para manajemen dalam bentuk penyediaan informasi serta pengetahuan yang relevan, tepat, akurat, terpercaya dan bernilai tinggi (Sebayang, 2010:325).

Informasi yang ada pada perbankan merupakan keberhasilan dari sebuah implementasi teknologi informasi sehingga digunakan oleh pihak perbankan untuk melayani nasabah (Sebayang, 2010:336). Semua lambaga keuangan khususnya perbankan syariah pada masa sekarang sudah memiliki layanan website yang terus meningkatkan kualitas penggunaan, kualitas informasi, dan kualitas interaksi online dengan nasabahnya. Sehingga teknologi informasi mampu mengakomodasi semua kebutuhan nasabah agar terjalin hubungan yang erat bahkan bersifat pribadi antara pihak bank dan nasabah (Adi, 2018:474). Salah satu website bank yang digunakan oleh masyarakat yaitu website BNI Syariah.

Keunggulan BNI Syariah tersebut menjadikan website yang digunakannya terus berkembang dan memberikan kemudahan akses produk dan layanan perbankan syariah serta informasi perusahaan yang akurat (Muslim, 2012:92). Prestasi tersebut menjadikan tolak ukur bagi bank lainnya untuk tetap mengoptimalkan layanan website yang dikelolanya. Maka dari itu kualitas layanan website bank syariah menjadi penting bagi BNI Syariah untuk memberikan informasi kepada para nasabahnya. 


\section{MATERI DAN METODE}

Layanan merupakan segala kegiatan yang ditujukan untuk menyiapkan sarana baik online maupun offline untuk mempermudah perolehan informasi yang dibutuhkan (Aripudjiastono, 2010:2). Islam memberikan pedoman bagi para pelaku usaha agar memberikan pelayanan yang baik kepada nasabah didalam AlQur'an (Al-Imran 159)
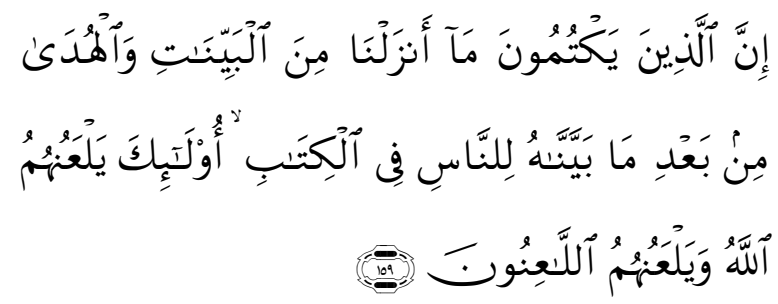

Ayat tersebut menjelakan mengenai bersikap lemah lembut dan melarang bersikaf keras kepada sesama. Artinya dalam kegiatan usaha pentingnya kualitas layanan dari segala aspek untuk diberikan kepada nasabah agar menciptakan suatu kepuasan dan terciptanya loyalitas nasabah (Saidani, 2012:5; Rossela, 2010).

Website merupakan sistem yang secara universal dapat menyimpan, mengambil, memformat serta menampilkan informasi menggunakan arsitektur klien dengan cara mengkombinasikan teks, grafis serta suara yang tersimpan dalam serverweb internet yang disajikan dalam bentul hiperteks. Melalui website masalah perdagangan yang kompleks sudah bisa diatasi dengan menggunakan alat teknologi informasi internet, hampir semua perusahaan bisnis mempunyai website untuk menyampaikan informasi atau melakukan kesepakatan pada suatu bisnisnya (Rahadi, 2011:20).

Kualitas website mempengaruhi tiga hal yaitu kualitas sistem (System quality), kualitas pelayanan (sevice quality) dan kualitas informasi (information quality). Kualitas website dirasakan akan mempengaruhi pengguna untuk terus menggunakan situs tersebut (Farihah, 2017:10). Situs online secara signifikan penting untuk kegiatan bisnis dengan fitur-fitur inovatif sehingga dapat berkembang pesat. Untuk itu perusahaan harus mengembangkan website berkualitas tinggi yang memberikan pengalaman online yang lebih baik untuk menarik dan mempertahankan pelanggan (Latifah Zulfa, 2018:2).

Adapun faktor-faktor penilaian kualitas website yaitu 1) kualitas pengguna yang terdiri dari desain website, sistem navigasi, dan aksesibilitas. 2) Kualitas informasi yang terdiri dari konten, relevan, informasi terkini. 3) kualitas interaksi terdiri dari kepercayaan, keamanan bertransaksi, kemudahan berkomunikasi. Pelayanan dalam website dapat diukur untuk mengetahui tingkat kepuasan pengguna sehingga diperoleh nilai kualitas layanan. Maka pemberi layanan jasa bank harus mengukur kualitas layanan berdasarkan selera pelanggan. Karena nasabah merupakan orang yang menerima hasil dari layanan website (Monalisa, 2016:182).

BNI Syariah merupakan lembaga keuangan yang mengembangkan layanan website untuk memberikan informasi kepada nasabah, sehingga penyebaran informasi lebih meluas dengan adanya layanan website tersebut. Penelitian terdahulu yang pernah dilakukan oleh An Nissa Puspitasari (2013) mengenai Kualitas website terbukti memiliki pengaruh terhadap nilai yang dipersepsikan pelanggan. Hal ini menunjukan bahwa dimensi kualitas website yaitu kualitas informasi, keamanan, kenyamanan, kemudahan, serta kualitas layanan telah menghasilkan nilai dengan memberikan manfaat yang terkait. Konsumen yang percaya pada informasi yang yang diberikan di website akan merasakan bahwa produk tersebut merupakan suatu nilai terbaik untuk dibelanjakan. Berarti dengan selalu memperbaharui informasi website serta menyajikan informasi secara tepat dan akurat akan meningkatkan nilai yang dipersepsikan terhadap produk. 
Penerapan layanan berbasis website bisa berhasil jika berbagai faktor penggerak layanan berjalan dengan baik. Ketersediaan infrastruktur, sumber daya manusia yang berkompeten, serta dengan dukungan perangkat keras dan lunak yang memenuhi kebutuhan teknologi informasi dari institusi yang bersangkutan. Penerapan layanan website juga perlu didukung dengan adanya tingkat kualitas layanan yang baik kepada penggunanya (Kasmir, 2013; Kesuma, 2014:180).

Penelitian ini bertempat di wilayah kota Bogor dan sekitarnya. Waktu penelitian ini adalah pada bulan Februari 2019. Terdapat beberapa teknik pengumpulan data yang digunakan dalam penelitian adalah: Kuesioner yang merupakan suatu metode pengumpulan data yang dilakukan dengan cara memberikan lembaran kuesioner yang berisi pernyataan kepada responden. Kuesioner pada penelitian ini menggunakan skala likert yaitu skala pengukuran yang berhubungan dengan pertanyaan tentang pendapat responden terhadap suatu jawaban yang telah diberikan oleh responden.

Teknik analisis pada penelitian ini adalah teknik analisis faktor, yang digunakan untuk menjawab permasalahan yang berkaitan dengan faktor manakah yang paling dominan yang mempengaruhi kualitas layanan website terhadap perolehan informasi nasabah di BNI Syariah. Analisis faktor didefinisikan sebagai suatu teknik analisis statistik multivariate yang biasa digunakan untuk mengurangi/ mereduksi/ meringkas setiap variabel terikat dan saling ketergantungan.

Pada penelitian ini sampelnya adalah masyarakat Bogor Utara dengan jumlah 196,051 yang menjadi bagian dari populasi. Besaran sampel ditentukan dengan cara menghitung ukuran sampel yang dilakukan dengan menggunakan teknik slovin (Sugiyono, 2011:87). Dalam menggunakan rumus slovin penarikan sampel jumlahnya harus representative agar hasil penelitian dapat di generalisasikan dan perhitungannya pun tidak memerlukan tabel jumlah sampel, namun dapat dilakukan dengan rumus dan perhitungan sederhana, menggunakan teknik slovin. Rumus slovin untuk menentukan sampel adalah sebagai berikut:

$$
\mathrm{n}=\frac{N}{1+N(e)^{2}}
$$

Keterangan:

$\mathrm{n}=\quad$ Ukuran sampel atau jumlah responden

$\mathrm{N}=$ Ukuran pupolasi

$\mathrm{E}=$ Persentase kelonggaran ketelitian kesalahan pengambilan sampel yang masih bisa ditolelir $\mathrm{e}=0,1$

Dalam rumus slovin ada ketentuan sebagai berikut:

Nilai e $=0,1(10 \%)$ untuk populasi dalam jumlah besar nilai $e=0,2(20 \%)$

Jadi rentang sampel yang dapat diambil dari teknik slovin adalah antara 10-20\% dari populasi penelitian jumalah populasi dalam penelitian ini 196,051 jiwa, sehingga persentase kelonggaran yang digunakan adalah $10 \%$ dan hasil perhitungan dapat dibulatkan untuk mencapai kesesuaian. Maka untuk mengetahui sampel penelitian, dengan perhitungan sebagai berikut:

$\mathrm{n}=\frac{196,051}{1+196,051(0,1)^{2}}$

$\mathrm{n}=\frac{196,051}{1,961.51}=99,94$ disesuaikan oleh peneliti menjadi 100 responden.

Berdasarkan perhitungan diatas sampel yang menjadi responden dalam penelitian ini di sesuaikan menjadi sebanyak 100 orang. 


\section{HASIL DAN PEMBAHASAN}

BNI Syariah sebagai Bank Umum Syariah (BUS) yang merealisasikan waktu spin off pada bulan Juni 2010 yang tidak terlepas dari faktor eksternal berupa aspek regulasi yang kondusif yaitu dengan diterbitkannya UU No.19 tahun 2008 tentang Surat Berharga Syariah Negara (SBSN) dan UU No. 21 tahun 2008 tentang perbankan syariah. BNI Syariah sebagai lembaga keuangan syariah yang perlu menetapkan visi misi adapun visi misinya sebagai berikut:

Analisis deskriptif demografi responden menjelaskan mengenai informasi jenis kelamin, usia, pendidikan terakhir, lama menjadi nasabah BNI Syariah, pernah membuka website BNI Syariah dan domisili. Jumlah responden pada penelitian ini yaitu 100 responden nasabah BNI Syariah yang pernah membuka website BNI Syariah dan bertempat tinggal dikota Bogor (Bogor Utara).

Jenis Kelamin Responden. Demografi jenis kelamin berisi pertanyaan yang terkait dengan jenis kelamin responden. Dilihat dari 100 kuesioner yang disebar kepada responden, mayoritas responden mengisi kuesioner ini adalah perempuan dengan jumlah 57 orang dan laki-laki dengan jumlah 43 orang.

Usia Responden Usia responden berisi pertanyaan terkait usia responden. Berdasarkan kuesioner yang diisi oleh 100 responden hasilnya adalah yang mengisi kuesioner berusia kurang dari 20 tahun sebanyak 4 orang, responden dengan usia 20-30 tahun sebanyak 71 orang, responden yang berusia 30-40 tahun sebanyak 22 orang dan responden yang berusia lebih dari 40 tahun sebanyak 3 orang.

Jika kita lihat dari hasil data pada gambar 4.2, responden lebih banyak berusia 20-30 tahun, dengan demikian bahwa responden memilih menggunakan layanan website karena merasa lebih memudahkan untuk mendapatkan informasi yang dicari, sehingga usia tersebut adalah usia yang mampu memahami layanan website dengan baik.

Demografi Pendidikan Terakhir Responden Demografi pendidikan terakhir berisi pertanyaan terkait pendidikan terakhir responden. Berdasarkan dari 100 kuesioner yang diisi oleh responden mayoritas responden dengan pendidikan terakhir SLTA sebanyak 52 orang, S1 sebanyak 40 orang, S2 sebanyak 7 orang dan SMP sebanyak 1 orang.

\section{Lama Menjadi Nasabah BNI Syariah}

Lama menjadi nasabah BNI Syariah berisi pertanyaan dengan tujuan mengetahui informasi lamanya responden menjadi nasabah BNI Syariah. Berdasarkan 100 kuesioner yang disebarkan, mayoritas responden menjadi nasabah BNI Syariah kurang dari satu tahun dengan jumlah 38 orang dan lebih dari satu tahun berjumlah 62 orang.

Jika dilihat dari gambar 4.4, lamanya menjadi nasabah terbanyak mengisi kuesioner adalah nasabah yang lebih dari satu tahun. Hal ini menunjukan bahwa nasabah yang sudah lama akan terus memperhatikan pelayanan yang diberikan oleh bank salah satunya pelayanan yang diberikan lewat website bank tersebut.

\section{Uji Validitas dan Realibilitas}

Uji Validitas digunakan untuk mengetahui tingkat keandalan suatu data. Instrumen yang dikatakan valid dan dapat digunakan untuk mengukur tingat validitas suatu data. Uji validitas dari semua item pertanyaan ini yang berjumlah 36 pertanyaan menunjukan nilai nilai Corrected Item-Total Correlation $>0,361$. Ini artinya bahwa semua item pertanyaan dinyatakan valid dan dapat diolah ketahap selanjutnya.

Sedangkan uji reliabilitas digunakan untuk mengetahui sejauh mana instrumen pengukuran dapat dipercaya dan memberikan hasil yang konsisten. Hasil pengujian reliabilitas yang diuji dari 
semua pernyataan dinyatakan reliabel, karena nilai koefisien cronbach alpha diperoleh lebih besar dari 0,60 ( $a>0,60$ ) yaitu sebesar 0 , 974. Dengan demikian instrumen yang digunakan dalam penelitian ini cukup handal dalam mengukur responden terhadap variabel yang diteliti dan dapat dilanjutkan ketahap selanjutnya.

Langkah awal yang dilakukan dalam mengolah data dengan analisis faktor adalah menilai indikator atau variabel yang dianggap layak dan telah diuji validitasnya untuk dimasukan dalam penguraian selanjutnya. Proses analis faktor dapat dilihat pada tahapan berikut ini:

\section{Uji Kaiser Mayer Olkin.}

Dari hasil pengolahan data menggunakan program SPSS 21 diperoleh Of Sampling Adequacy (KMO-MSA) sebesar 0,920. Hasil ini termasuk pada hasil kategori mengingat angka ini sudah diatas 0,5. Adapun nilai Bartlett's Test of Sphericity mempunyai nilai 913,648 dengan nilai signifikansi 0,000 . Nilai ini berarti bahwa faktor pembentuk variabel sudah baik serta boleh dianalisis ketahap selanjutnya.

\section{Proses Ekstraksi}

Hasil penelitian menunjukan bahwasanya indikator yang memiliki nilai extraction tertinggi adalah kualitas yang berkaitan dengan kemudahan berkomunikasi dengan nilai sebesar 0,895 . Hal ini berarti $89,5 \%$ varian variabel kualitas keumudahan berkomunikasi sudah terbentuk. Kemudian untuk variabel relevan85,5\%, aksesibilitas 82,9\%, keamanan transaksi $82,4 \%$, konten $79,6 \%$, sistem navigasi $79,6 \%$, dan variabel desain website mempunyai nilai extraction terendah $77,8 \%$. Hal ini berarti $77,8 \%$ varian dari variabel desain website dapat dijelaskan oleh faktor yang akan terbentuk. Variabel yang semakin besar nilai communalities nya menunjukan semakin kuat hubungan dengan faktor yang nantinya akan terbentuk.
Selanjutnya

berdasarkan pengolahan data dengan SPSS 21 didapatkan hasil bahwa 9 indikator yang digunakan dalam penelitian ini akan dikelompokan ke dalam 2 faktor yaitu:

Faktor pertama yang memiliki nilai eigenvalue sebesar 6,859 dengan varian 76, 213 persen. Faktor kedua Faktor kedua memiliki nilai eigenvalue sebesar 0,522 dengan varian 5,795 persen.

Hasil tersebut menunjukan bahwa faktor 1 mampu menjelaskan seluruh varians sebesar 76, 213\%, dan faktor 2 menjelaskan seluruh varians sebesar 5,795\%. Sedangkan berdasarkan komulatif seluruh faktor dapat menjelaskan varians sebesar 82,008\%. Hal ini berarti masih terdapat variabelvariabel lain menjadi indikator dalam pengaruh kualitas layanan website terhadap perolehan informasi nasabah BNI Syariah kota Bogor.

Setelah mendapat 2 faktor adalah jumlah faktor yang paling optimal, maka analisis selanjutnya dilakukan pada compenent matrix yang menunjukan distribusi 9 variabel pada 2 faktor yang terbentuk. Angka-angka yang terdapat pada tabel component matrix merupakan factor of loading yang menunjukan besar korelasi antara suatu variabel dengan faktor pertama dan kedua. Proses penentuan variabel asal ke dalam faktor dilakukan dengan membandingkan besar korelasi tiap baris yang didasarkan pada angka mutlak pada factor of loading yang diberikan setiap variabel terhadap masing-masing faktor .

Berdarkan nilai component matrix terlihat bahwasanya keseluruhan variabel berada pada faktor 1 dengan nilai factor of loading lebih dari 0,5 dan tidak ada indikator yang masuk kepada faktor 2 karena keseluruhan nilai factor of loading kurang dari 0,5. Padahal syarat suatu indikator masuk ke dalam suatu faktor yaitu factor of loading harus di atas 0,5. Maka dari itu, perlu adanya proses rotasi agar component 2 memiliki nilai faktor of loading yang besar, sehingga dapat 
terlihat variabel mana yang masuk pada component 2. Proses rotasi menggunakan metode varimax yang bertujuan untuk memperbesar nilai factor of loading yang awalnya memang sudah besar dan memperkecil nilai factor of loading yang awalnya memang sudah kecil.

Setelah dilakukan rotasi, maka dapat dengan mudah menentukan indikator-indikator mana yang akan masuk ke dua fsktor tersebut. Dari hasil rotated component matrix dapat dilihat bahwa indikator yang termasuk dalam component 1 yaitu indikator sistem navigasi $(0,696)$, aksesibilitas $(0,835)$, konten $(0,742)$, relevan $(0,841)$, kepercayaan $(0,685)$. Hasil ini dinyatakan bahwa indikator tersebut mempunyai korelasi yang tinggi terhadap faktor 1 . Kemudian untuk component 2 yaitu indikator desain website $(0,700)$, informasi terkini $(0,771)$, keamanan transaksi $\quad(0,830), \quad$ kemudahan berkomunikasi $(0,850)$.

Hasil analisis faktor dengan 9 indikator yang diteliti menggunakan metode ekstraksi principle component analysis yang direduksi menjadi 2 faktor dimana indikator sistem navigasi, aksesibilitas, konten, relevan, kepercayaan menjadi faktor 1 . Sedangkan indikator desain website, informasi terkini, keamanan transaksi, kemudahan berkomunikasi termasuk kepada faktor 2 .

\section{Penamaan Faktor}

Berdasarkan hasil penelitian dari analisis faktor yang telah dijelaskan di atas, maka dapat ditemukan persamaan kedua faktor yaitu sebagai berikut:

$$
\begin{aligned}
\mathrm{F} 1= & 0,841 \text { Relevan }+\quad 0,835 \\
& \text { Aksesibilitas }+0,742 \text { Konten+ } \\
& 0,696 \text { Sistem navigasi }+0,685 \\
& \text { Kepercayaan. }
\end{aligned}
$$

Faktor utama ini memiliki nilai eigenvalue sebesar 6,859 bahwa faktor ini merupakan faktor yang paling dominan atau yang paling mempengaruhi kualitas layanan website BNI syariah kota Bogor. Faktor 1 dapat mempengaruhi keragaman data sebesar 76,213 persen.

$$
\begin{aligned}
\mathrm{F}_{2}= & 0,700 \text { desain website }+0,771 \\
& \text { informasi terkini }+0,830 \\
& \text { Keamanan } \\
& \text { bertransaksi+ 0,850 kemudahan } \\
& \text { berkomunikasi }
\end{aligned}
$$

Dalam penelitian ini, terdapat dua pertanyaan yang menjadi fokus penelitian yaitu pertama, Faktor apa saja yang mempengaruhi kualitas layanan website BNI syariah terhadap perolehan informasi nasabah. Untuk menjawab pertanyaan penelitian ini bahwa faktor apa saja yang mempengaruhi kualitas layanan website BNI Syariah terhadap perolehan informasi nasabah yaitu dengan melihat bahwa semua faktor dapat mempengaruhi yaitu kualitas penggunaan, kualitas informasi, kualitas interaksi yang meliputi indikator desain website, sistem navigasi, aksesibilitas, konten, relevan, informasi terkini, kepercayaan, keamanan transaksi, dan kemudahan berkomunikasi. Dilihat dari persentase varians sebesar 82,008 persen, yang menunjukan adanya pengaruh terhadap perolehan informasi nasabah.

Pertanyaan kedua pada penelitian ini adalah Faktor apa yang paling dominan pada layanan website BNI Syariah terhadap perolehan informasi nasabah. Dari pertanyaan kedua ini, terdapat hipotesis yang harus dibuktikan yaitu sebagai berikut:

Hipotesis Pertama

$\mathrm{H}_{0}$ : Variabel kualitas pengguna tidak mempengaruhi perolehan informasi nasabah

$\mathrm{H}_{1}$ : $\quad$ Variabel kualitas pengguna mempengaruhi perolehan informasi nasabah

Berdasarkan hasil analisis faktor desain website (,700), sistem navigasi (,696), aksesibilitas (,835) merupakan faktor yang mempengaruhi kualitas layanan website BNI syariah Kota Bogor terhadap perolehan informasi nasabah maka dapat dikatakan bahwa $\mathrm{H}_{0}$ ditolak dan $\mathrm{H}_{1}$ diterima. Hipotesis Kedua 
H0: Variabel kualitas informasi tidak mempengaruhi perolehan informasi nasabah

$\mathrm{H}_{1}$ : Variabel kualitas informasi mempengaruhi perolehan informasi nasabah

Berdasarkan hasil analisis faktor konten (,742), relevan (,841), informasi terkini (,771) merupakan faktor yang mempengaruhi kualitas layanan website BNI syariah Kota Bogor terhadap perolehan informasi nasabah maka dapat dikatakan bahwa $\mathrm{H}_{0}$ ditolak dan $\mathrm{H}_{1}$ diterima.

Hipotesis Ketiga

H0: Variabel kualitas interaksi tidak mempengaruhi perolehan informasi nasabah

H1: Variabel kualitas interaksi mempengaruhi perolehan informasi nasabah

Berdasarkan hasil analisis faktor kepercayaan (,685), keamanan bertransaksi (,830), kemudahan berkomunikasi $(850)$ merupakan faktor yang mempengaruhi kualitas layanan website BNI syariah Kota Bogor terhadap perolehan informasi nasabah maka dapat dikatakan bahwa H0 ditolak dan H1 diterima.

Berdasarkan penjelasan di atas menunjukan bahwa faktor sistem navigasi, aksesibilitas, konten, relevan, dan kepercayaan merupakan faktor yang paling dominan mempengaruhi kualitas layanan website BNI syariah Kota Bogor terhadap perolehan informasi nasabah.

\section{KESIMPULAN DAN IMPLIKASI}

Kesimpulan memuat temuan hasil Berdasarkan hasil penelitian mengenai faktor-faktor yang mempengaruhi kualitas layanan website bank syariah terhadap perolehan informasi nasabah (Studi BNI Syariah Kota Bogor), dapat ditarik kesimpulan, sebagai berikut: Faktor-faktor yang mempengaruhi kualitas layanan website bank syariah adalah kualitas penggunaan, kualitas interksi, kualitas informasi yang meliputi sistem navigasi $(0,696)$, aksesibilitas $(0,835)$, konten $(0,742)$, relevan $(0,841)$, dan kepercayaan $(0,685)$, desain website $(0,700)$ informasi terkini $(0,771)$, keamanan bertransaksi $(0,830)$. Kemudahan berkomunikasi $(0,850)$. Faktor utama yang mempengaruhi kualitas layanan website BNI Syariah terhadap perolehan informasi nasabah di Kota Bogor pada penelitian ini adalah relevan dengan nilai 0,841 , aksesibilitas dengan nilai 0,835 , konten dengan nilai 0,742 , sitem navigasi dengan nilai 0,696 dan kepercayaan dengan nilai 0,685.

Adapun saran yang yang dapat disampaikan setelah melakukan penelitian adalah: BNI Syariah merupakan salah satu bank yang memiliki prestasi sebagai layanan website yang baik, diharapkan BNI Syariah mampu mempertahankan prestasi yang telah diraihnya sehingga mampu memberikan layanan informasi yang baik kepada nasabahnya. Agar BNI Syariah lebih berfokus pada faktor yang paling dominan yaitu faktor relevan. BNI Syariah perlu meningkatkan kualitas informasi secara relevan untuk kepuasan nasabah. Relevan disini seperti dilihat dari pengelolaan layanan website yang menyajikan informasi yang akurat. Diharapkan hasil penelitian ini mampu menjadi acuan kepada peneliti selanjutnya yang akan meneliti dengan konsep yang sama, tidak sampai pada mengetahui faktor dominanny a saja namun dilanjutkan kepada hal yang lebih spesifik agar hasil penelitian lebih variatif.

\section{DAFTAR PUSTAKA}

Abdullah, D. (2016). Desain website.

Adi, M S. (2018). Pengaruh Kualitas Layanan Online Terhadap Kepuasan Komitmen dan Loyalitas Nasabah Internet Banking di Kota Denpasar. 
Jurnal Inovasi Bisnis dan Manajemen Indonesia, Vol. 1 No 4, 473-488.

Adityo, B. (2011). Analisis Pengaruh Kepercayaan, Kemudahan, Dan Kualitas Informasi Terhadap Keputusan Pembelian Secara Online Disitus Kaskus. Semarang: Fakultas Ekonomi Unviersitas Diponegoro.

Akbar, A. (2015). Analisis Dimensi Kualitas Website E-commerce Terhadap Kepuasan dan Implikasinya Pada Loyalitas Pengguna. Jurnal Ilmiah Komputasi, Vol, 14 No. 2. Desember 2015, 1117.

Ali, H. (2010). Marketing Bank Syariah. Bogor : Ghalia Indonesia.

Ariani, D. (2014). Modul 1 Manajemen Kualitas . Universitas Terbuka.

Arikunto. (2006). Prosedur Penelitian Suatu pengantar Praktik. Jakarta : Rineka Cipta.

Aripudjiastono. 2010. Layanan Promosi dan Kerjasama dan Perpustakaan

Bariyati, N. (2018). The Role Customer Service In Improving Customer satisfaction Bank Jatim Branch Jombang. Surabaya: Fakultas Perbankan dan Keuangan Sekolah Tinggi Ilmu Ekonomi Perbanas.

Bawono, A. (2006). Multi Variate Analisis Dengan SPSS. Salatiga : STAIN

Baskara, I. P. (2014). Analisis Pengaruh Kepercayaan, Keamanan, Kualitas Pelayanan dan Persepsi Akan Resiko Terhadap Keputusan Pembelian Melalui Situs Jejaring Sosial . 1-15.

Bodnar, G. H. (2000). Sistem Informasi Akuntansi. Jakarta: Salemba Empat.
Bimo, W A. (2018). Ditgitalisasi Bank Terhadap Peningkatan Pelayanan dan Kepuasan Nasabah. Jurnal Manajemen. Vol. 7 No. 1, 14-34.

Brawijaya, Andri dan Metti Paramita. (2018). Persefsi Masyarakat Mengenai Service Excellence Pria dan Wanita Terhadap Loyalitas Nasabah. Jurnal Nisbah. Vol 4 No. 2, 122- 131

Ciptaningrum, D. (2015). Audit Keamanan Sistem Informasi Pada Kantor Pemerintah Kota Yogyakarta Menggunakan COBIT 5. Jurnal Seminar Nasional Teknologi Informasi dan Komunikasi. Vol 1 No 2 65-74.

Dianingtyas, B. s. (2004). Pengaruh Kualitas Informasi Website Terhadap Citra Pemerintah Kabupaten Wonogiri. Yogyakarta: Fakultas Ekonomi Sosial Dan Politik.

Djadja, H. (2014). Analisis Terhadap Hak Cipta Konten Informasi Elektronik Pada Situs Informasi. Jurnal Cakrawala Hukum. Vol. 5 No.2 Desember , 139-150

Ernesto, E. B. (2018). Analisis Kualitas Website Tribunnews. Com Menggunakan Metode Webqual dan Importance Performance Analysis. Jurnal Pengembangan Teknologi Informasi dan Ilmu Komputer. Vol. 2 No. 4, 1483-1491.

Farida, U. (2013). Pengaruh Aksesibilitas Terhadap Karakteristik Sosial Ekonomi Masyarakat Pedesaaan Kecamatan Bumi Jawa Kabupaten Tegal. Jurnal Wilayah dan Lingkungan. Vol. 1 No. 1, 49-66. 
Farihah, A. (2017). Pengaruh Kepercayaan Citra Merek Kualitas Website dan Harga Terhadap Minat Beli Pada Bukalapak. Jakarta: Universitas Islam Negeri syarif Hidayatullah.

Hanifa, A. (2017). Analisis Technologi Acceptance Model (TAM) Terhadap Penggunaan Layanan Internet Banking Study di Bank Rakyat Indonesia Syariah Cabang Surakarta. Surakarta: IAIN Surakarta.

Hapsari, S. (2010). Pembuatan Website Pada Google Original Movie Rental Pacitan. Jurnal Speed- Sentra Penelitian Engineering dan Edukasi. Vol 2. No. 2, 50-61.

Harminingtyas, R. (2014). Analissi Layanan Website Sebagai Media Promosi Media Transaksi dan Media Informasi dan Pengaruhnya Terhadap Brand Image Perusahaan pada Hotel Ciputra. Jurnal STIE Semarang. Vol. 6 No. 3, 37-57.

Hidayat, N. (2017). Faktor-Faktor Yang Mempengaruhi Motivasi Mahasiswa Menjadi Enterpreneur Syariah. Bogor: Universitas Djuanda Bogor.

Ichsani, Y. (2017). Evaluasi Performa Usability Situs-situs Web Perguruan Tinggi Negeri di Indonesia yang Terakreditasi A Tahun 2013 Serta Perbandingan Kondisi Situs Web Tahun 2014 dan 2015. Jurnal Teknik Informatika Vol.10 No. 2. 93-108.

Kardoyo. (2018). Program Peningkatan Literasi Keuangan Syariah Bagi Guru Taman Pendidikan Alquran di Kota Semarang. Jurnal Pengabdian Kepada Masyarakat Vol. 24 No. 2. 655-660.

Kasmir. (2013). Kewirausahaan. Jakarta : Rajawali Pers.
Kesuma, D. P. (2014). Analisis Pengukuran Kualitas Layanan Web Perguruan Tinggi XYZ Menggunakan Servqual. Jurnal Seminar Informatika, 178-183.

Khakim, L. (2015). Pengaruh Kualitas Pelayanan Harga dan Kepercayaan Terhadap Loyalitas Pelanggan Dengan Variabel Kepuasan Pelanggan Sebagai Variabel Intervening Pada Pizza Hut Cabang Simpang Lima. Jurnal Of Mangement. Vol. 1 No. 1. 1-24.

Kosasi, S. (2015). Pengukuran Kinerja Web Brinet System Dengan Metode IT Balanced Scorecard. Jurnal Buana Informatika. Vol. 6 No. 1, 1-10.

Krisdiantoro. (2018). Pengaruh Kualitas Sistem dan Kualitas Informasi Terhadap Manfaat Bersih Dengan Intensitas Penggunaan Sebagai Variabel Mediasi. Jurnal Akuntansi Aktual. Vol, 5 No. 2, 149-167.

Kusumaningsih, I. (2015). Pengelolaan Website Sebagai Media Pelayanan Informasi Publik Oleh Bagian Hubungan Masyarakat Sekretariat Negara RI. Malang: Universitas Brawijaya.

Mahrus, A. (2010). Web Design Pemrograman Web. Pondok Gede : Pranata Indah.

Margono. (2004). Metodologi Penelitian Pendidikan. Jakarta : Rineka Cipta.

Monalisa, S. (2016). Analisis Kualitas Layanan Website Terhadap Kepuasan Mahasiswa Dengan Penerapan Metode Webqual. Jurnal Sains Teknologi dan Industri. Vol 13 No. 2, 181-189.

Munir, A. R. (2013). Faktor- Faktor Yang Mempengaruhi Bhvioral Intention 
Nasabah Untuk Menggunakan Layanan Mobile Banking di Sulawesi Selatan. Sulawesi Selatan: Universitas Hasanudin.

Muslim. (2012). Pengembangan Sistem Informasi Jurusan Berbasis Web Untuk Meningkatkan Pelayanan Dan Akses Informasi. Jurnal MIPA. Vol. 35 No. 1. 92-98.

Nazir. (2005). Metode Penelitian. Jakarta : Ghalia Indonesia.

Nazir, M. (2014). Metode Penelitian. Bogor : Ghalia Indonesia.

Pradiva, K. K. 2018. Keamanan Informasi

Pratama, R D. (2014). Persepsi User Terhadap Desain Website ECommmerce Studi Pada Pengguna Website JKM Store. Jurnal Administrasi Bisnis, Vol, 9 No. 1. April 2014, 1-6.

Rahadi, D. R. (2011). Pengaruh Karakteristik Website Terhadap Kepuasan Pelanggan. Jurnal Teknologi Informasi Politeknik Telkom. Vol. 1 No. 1 20-25.

Rossela. (2010). Hubungan Antara Kualitas Layanan Dengan Kepuasan Pemakai Perpustakaan STT PLN. Jakarta: Universitas Islam Negeri Syarif Hidayatullah

Rumah, Web. 2005. Merancang Navigasi Web

Saidani, B., dan Arifin S. (2012). Pengaruh Kualitas Produk Dan Kualitas Layanan Terhadap Kepuasan Konsumen Dan Minat Beli Pada Branch Market. Jurnal Riset Manajemen Sains Indonesia. Vol. 3 No. 1. 1-22.
Salam, A. (2018). Inklusi Keuangan Perbankan Syariah Berbasis Digital Banking Optimalisasi Dan Tantangannya. Jurnal Al-Amwal. Vol. 10 No. 1, 63-80.

Santoso, B. S. (2015). Analisis Kualitas Website Menggunakan Metode Webquql dan Importance Permformance Analisis (IPA) Pada Situs KASKUS.

Santoso, I R. (2018). Sosialisasi dan Pelatihan Implementasi Akad-akad dan Produk Perbankan Syariah. Jurnal Pengabdian Masyarakat.Vol. 3 No. 2 151-158.

Sebayang, F., dan Husada Z j. (2010). Ketersediaan Sistem Informasi Terintegrasi Terhadap Kepuasan Pengguna. Jurnal Keuangan dan Perbankan. Vol, 13 No. 2, 325-336.

Sihotang, E. T. (2010). Faktor Penentu yang Mempengaruhi Penggunaan Layanan Internet Banking. Jurnal Ekonomi dan Manajemen Vol. 13 No.1. 25-36.

Subekti, I. (2012). Relevansi Nilai Atas Informasi Akuntansi, Struktur Kepemilikan Saham dan Afiliasi Group Bisnis Pada Perusahaan Publik di Indonesia. 1-23.

Sugiono. (2007). Metode Penelitian Kuantitatif Kualitatif. Bandung : Alfhabeta.

Sugiyono. (2001). Statistika Untuk Penelitian. Bandung : Alphabeta.

Sugiyono. (2011). Metode Penelitian Kuantitatif Kualitatif dan R\&D. Bandung : Alphabeta.

Supranto, J. (2004). Analisis Multivariat Arti dan Interpretasi. Jakarta : Rineka Cipta. 
Suryani. (2016) Metode Riset Kuantitatif Teori dan Aplikasi Pada Penelitian Bidang Manajemen dan Ekonomi Islam. Jakarta : PT Fajar Interpratama Mandiri.

Trihantana, R. (2016). Analisis Mutu Layanan Electronic Delivery Chanel Terhadap Kepuasan Nasabah (Studi Pada BNI Syaraiah). Jurnal Nisbah Vol. 2 No.1. 160-166.

Utama, Y. (2011). Sistem Informasi Berbasis Web Jurusan Sistem Informasi Fakultas Ilmu Komputer Universitas Sriwijaya. Jurnal Sistem Informasi (JSI). Vol. 3 No. 2. 359-370.

Wicaksono, H. (2013). Layanan Referensi Berbasis Web yang Aksesibel Bagi Semua Orang. Jurnal Visi Pusaka. Vol 15 No. 2. 120-127.

Wijaya, A. (2014). Audit Tata Kelola Teknologi Informasi bagian Pengelolaan Data Menggunakan Fram Work COBIT 4.1 pada bank JATENG: Universitas Dian

Nuswantoro 